\title{
Smelting Reduction Process with a Coke Packed Bed for Steelmaking Dust Recycling
}

\author{
Yoshiaki HARA, Natsuo ISHIWATA, Hiroshi ITAYA and Toshiyuki MATSUMOTO'1) \\ Technical Research Laboratories, Kawasaki Steel Corporation, Kawasaki-cho, Chuo-ku, Chiba, 260-0835 Japan. \\ 1) Chiba Works, Kawasaki Steel Corporation, Kawasaki-cho, Chuo-ku, Chiba, 260-0835 Japan.
}

(Received on June 29, 1999; accepted in final form on September 10,1999)

\begin{abstract}
A new smelting reduction process with a coke packed bed has been developed for iron, chromium, and nickel recovery from BOF dust, and for simultaneous recovery of zinc and iron from the electric arc furnace dust. The process is characterized by direct use of fine raw materials without agglomeration, recovery of almost the whole amount of zinc and lead, and no emission of secondary waste, compared with the conventional recovery methods.

The commercial plant for BOF dust recycling has been operating stably with a metal production capacity of 200 tons per day. The blast condition is controlled so that the temperature at the lower tuyere level becomes higher than $1550^{\circ} \mathrm{C}$, which is the condition required for the smelting reduction of chromium and iron oxides.

The validity of the process idea for EAF dust recycling was confirmed and the key technologies were established through the pilot plant tests with a scale of 10 tons per day. It was found that zinc oxide was almost completely reduced and vaporized at the thermal state of the furnace, $T_{\text {melt }} \geqq 1550^{\circ} \mathrm{C}$, which allowed chromium and iron to be reduced. The control of the temperature and $\mathrm{CO}_{2} / \mathrm{CO}$ ratio of the top gas was important for the prevention of zinc adhesion on the wall of the furnace top.
\end{abstract}

KEY WORDS: coke packed bed; two stage tuyeres; smelting reduction; BOF dust; electric arc furnace dust; chromium; iron; zinc; thermal state of furnace; vaporization; zinc adhesion.

\section{Introduction}

Kawasaki Steel Corp. has developed a new smelting reduction process with a coke packed bed for steelmaking dust recycling. This smelting reduction process was developed originally for the production of ferro-alloys from fine ores. $^{1,2)}$ The features of the process against other ones ${ }^{3)}$ are 1) direct use of fine raw materials without agglomeration, 2) recovery of almost the whole amount of zinc and lead, and 3) no emission of secondary waste.

At first, the technologies developed for this process were applied for recycling BOF dust containing chromium and nickel $^{4)}$ which is generated in the steelmaking shop for smelting reduction of chromium ore in the converter. ${ }^{5)} \mathrm{A}$ commercial plant with a dust treatment capacity of 230 tons per day was started up in May, 1994, and has been successfully operating since.

Secondly, the technologies were applied for recycling electric arc furnace (EAF) dust containing zinc. The validity of the process idea was confirmed and the key technologies were established through pilot plant tests with a scale of 10 tons per day in $1996 .^{6-8)}$ The construction of the commercial plant for EAF dust recycling is now in progress.

In this report, the commercial plant and the recent operation of recycling the BOF dust containing chromium and nickel, and the pilot plant and the operation of recycling the
EAF dust containing zinc shall be described. Furthermore, the behavior of smelting reduction, the vaporization of the element in the furnace, and the prevention of zinc adhesion shall also be discussed.

\section{Concept of the Process}

The concept of this process is shown in Fig. 1. The process is characterized by:

(1) a shaft furnace with a coke packed bed,

(2) the use of two-stage tuyeres,

(3) direct use of fine raw materials without agglomeration,

(4) a simple smelting reduction furnace.

In this process, the two-stage tuyeres play a most important role and are effective for the smelting reduction of less reducible raw materials such as chromium ore.

Fine raw material is injected through the upper tuyeres and is fused immediately in the raceway. A high temperature and intensively reducible region is formed in the region between the two stages of tuyeres as a shaft furnace ensures a good heat exchange between the ascending gas and the descending coke. Thus, the molten oxides in the raw material are easily reduced to metal as it drips through the high temperature coke-packed bed. Reduced molten metal such as iron, chromium and nickel, and molten slag drip to the 


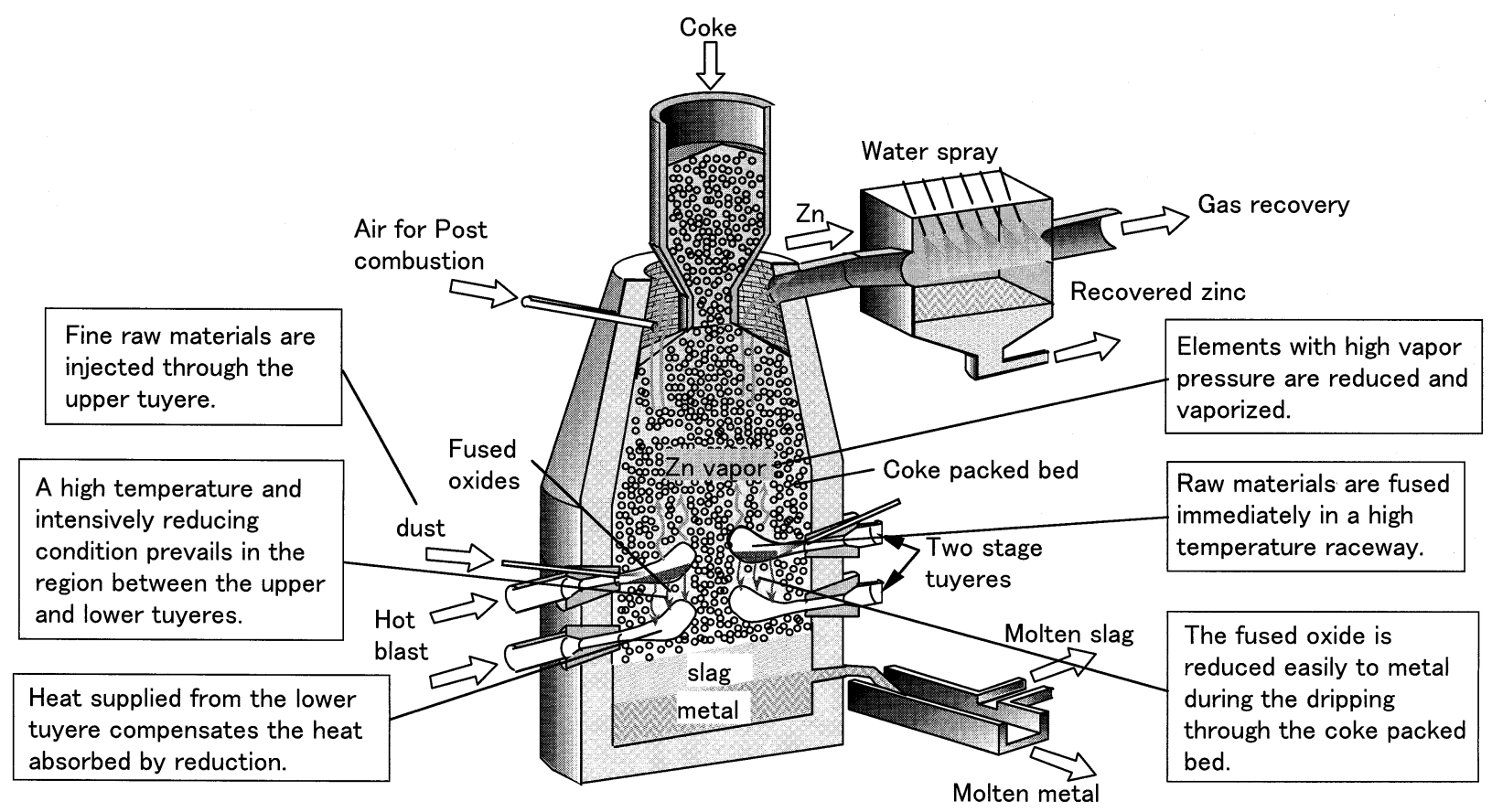

Fig. 1. Concept of the smelting reduction process for steelmaking dust recycling.

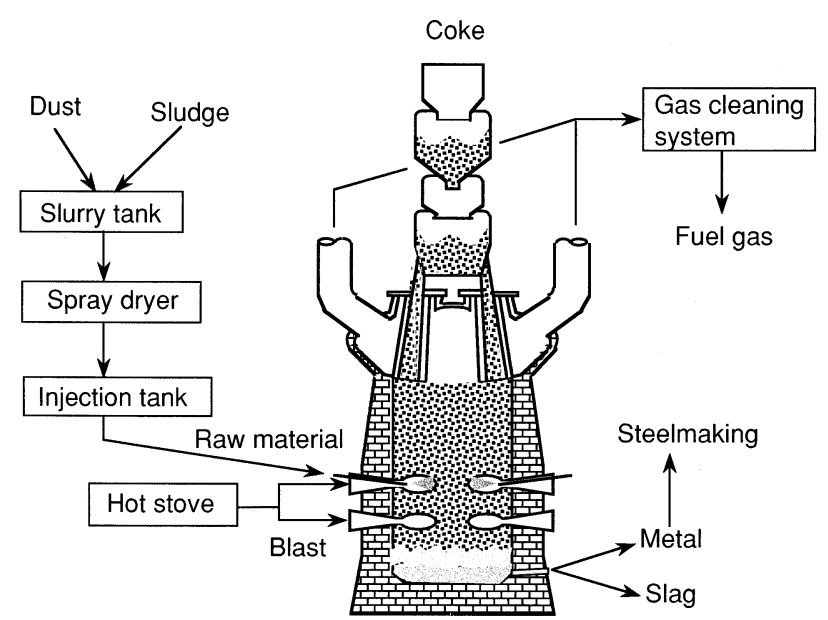

Fig. 2. Process flow of commercial plant for BOF dust recycling.

hearth, and elements with high vapor pressure such as zinc and lead are vaporized and extracted through the furnace top. Zinc and iron are separately recovered by this process. The smelting reduction consumes a huge amount of heat, but this heat requirement is easily met by the heat supplied from the lower tuyeres.

\section{Recycling of BOF Dust Containing Chromium and Nickel}

\subsection{Commercial Plant and Process Flow}

The process flow of the commercial plant for recycling BOF dust containing chromium and nickel, and the main specification are shown in Fig. 2 and Table 1. The raw materials are BOF dust and sludge from the pickling line. The dust and the sludge are mixed and stored in a slurry tank. The volume of the tank is large enough to store 4 days' worth of accumulated dust and sludge. The dust composition fluctuates according to the kinds of product at the steel-
Table 1. Main specification of commercial plant.

\begin{tabular}{|l|c|}
\hline Total volume & $140 \mathrm{~m}^{3}$ \\
\hline Hearth diameter & $4.0 \mathrm{~m}$ \\
\hline Furnace height & $11.5 \mathrm{~m}$ \\
\hline Number of tuyeres & $4 \times 2$ stages \\
\hline Number of iron notches & 1 \\
\hline
\end{tabular}

Table 2. An example of BOF dust composition.

\begin{tabular}{|c|c|c|c|c|}
\hline \multicolumn{1}{|c|}{ (mass\%) } \\
\hline T.Fe & T.Cr & T.Ni & SiO2 & CaO \\
\hline 56.0 & 6.3 & 0.4 & 1.1 & 1.1 \\
\hline
\end{tabular}

making shop, so this volume is effective to homogenize the dust composition. One problem in drying the dust is selfoxidation and fire. Rapid drying by a spray dryer ${ }^{9)}$ is used to protect the slurry from oxidation.

Dried raw material is transported pneumatically and injected from the upper tuyeres. Produced metal and slag are held in the hearth and tapped at an interval of $3 \mathrm{hr}$. The metal is cast with a casting machine and recycled to the steelmaking shop as a source of chromium and nickel. The by-product gas is used as a fuel in the works.

\subsection{Commercial Plant Operation}

The plant has been stably operating with a metal production of 200 tons per day. An example of BOF dust and typical operating conditions and results are shown in Tables 2 and 3. Iron and chromium in the dust exist as both metal and oxides.

The composition of produced metal and slag in the recent operation and the yield of the chromium are shown in Tables 4, 5 and 6. The composition of produced metal varies slightly with the composition of the dust. As shown in Tables 5 and 6, the chromium content of the slag is very low and the yield of chromium to metal is very high. The dust from the furnace, in which chromium content is only lower than 1 mass \%, is recycled to the sinter process. 
The control of the thermal state of the furnace is important for reduction of chromium oxide. In the commercial plant operation, both blast volume and oxygen enrichment are controlled according to the raw material feed rate so that the indicator of the thermal state, $T_{\text {melt }}$, becomes constant, as described later.

\section{Recycling of EAF Dust Containing Zinc}

\subsection{Process Flow of Pilot Plant}

The process flow of the pilot plant for recycling EAF dust containing zinc is shown in Fig. 3. The inner diameter of the furnace is $1.2 \mathrm{~m}$ and the height is $3.6 \mathrm{~m}$. One set of

Table 3. Recent typical operating conditions and results of commercial plant.

\begin{tabular}{|l|l|}
\hline Dust consumption & $287 \mathrm{t} / \mathrm{d}$ \\
\hline Blast volume & $209 \mathrm{Nm}^{3} / \mathrm{min}$ \\
\hline Oxygen enrichment & $56 \mathrm{Nm}^{3} / \mathrm{min}$ \\
\hline Metal production & $196 \mathrm{t} / \mathrm{d}$ \\
\hline Coke rate & $1066 \mathrm{~kg} / \mathrm{t}$-metal \\
\hline Slag rate & $436 \mathrm{~kg} / \mathrm{t}$-metal \\
\hline Metal Temperature & $1490{ }^{\circ} \mathrm{C}$ \\
\hline Top gas temperature & $730^{\circ} \mathrm{C}$ \\
\hline
\end{tabular}

Table 4. Composition of metal.

\begin{tabular}{|c|c|c|}
\multicolumn{2}{c}{ (mass\%) } \\
\hline $\mathrm{Cr}$ & $\mathrm{Ni}$ & $\mathrm{C}$ \\
\hline $7.5-9.1$ & $0.6-0.9$ & $4.1-4.5$ \\
\hline
\end{tabular}

Table 5. Composition of slag.

\begin{tabular}{|c|c|c|c|c|}
\hline $\mathrm{T} . \mathrm{Fe}$ & $\mathrm{T} . \mathrm{Cr}$ & $\mathrm{CaO}$ & $\mathrm{SiO}_{2}$ & $\mathrm{Al}_{2} \mathrm{O}_{3}$ \\
\hline $0.19-0.28$ & $0.12-0.27$ & $37-39$ & $36-38$ & $12-14$ \\
\hline
\end{tabular}

Table 6. Yield of chromium in the commercial plant operation.

\begin{tabular}{|c|c|c|}
\multicolumn{2}{c}{ (mass\%) } \\
\hline Metal & Slag & Dust \\
\hline 98.0 & 1.0 & 1.0 \\
\hline
\end{tabular}

the two stage tuyeres is installed in the pilot plant. Hot blast with enriched oxygen is blown through the two stage tuyeres. EAF dust is injected pneumatically through the upper tuyere with flux for adjusting the slag composition. Molten metal and slag are tapped from the hearth. On the other hand, zinc vapor carried with exhausted gas is quenched and collected by water spray in the quenching equipment and the venturi scrubber, and then recovered as slurry.

\subsection{Pilot Plant Operation}

Three campaigns of pilot plant tests were carried out. In a campaign, 30 tons of dust was continuously treated over a period of 3 days. Table 7 shows an example of the composition of the EAF dust used. The main component of the dust is zinc and iron that exist as oxides, but the dust contains small amounts of lead and other minerals. The operational conditions and results in three campaigns are shown in Table 8. In order to clarify the smelting reduction capacity, the injection rate of the dust was mainly varied under the constant blast conditions. Post combustion of the top gas was carried out to prevent the zinc adhesion on the wall of the furnace top.

Tables 9 and $\mathbf{1 0}$ show an example of the produced metal and slag, and the recovered zinc product. Zinc and lead were concentrated in the recovered product and the contents in the metal and the slag were very low. Figure 4 shows the

Table 7. An example of EAF dust composition.

\begin{tabular}{|c|c|c|c|c|c|c||l|}
\hline $\mathrm{T} . \mathrm{Zn}$ & $\mathrm{T} . \mathrm{Fe}$ & $\mathrm{Pb}$ & $\mathrm{C}$ & $\mathrm{SiO}_{2}$ & $\mathrm{Al}_{2} \mathrm{O}_{3}$ & $\mathrm{CaO}$ & Dioxin \\
\hline 27.7 & 25.0 & 3.22 & 3.33 & 2.78 & 2.09 & 2.16 & $1.4 \mathrm{ng} / \mathrm{g}$ \\
\hline
\end{tabular}

Table 8. Operational conditions and results in pilot plant tests.

\begin{tabular}{|l|c|}
\hline Blast volume & $900-1200 \mathrm{Nm}^{3} / \mathrm{h}$ \\
\hline Oxygen enrichment & $80-150 \mathrm{Nm}^{3} / \mathrm{h}$ \\
\hline Blast temperature & $750-800{ }^{\circ} \mathrm{C}$ \\
\hline Injection rate of EAF dust & $200-550 \mathrm{~kg} / \mathrm{h}$ \\
\hline Coke rate & $1,630-2,430 \mathrm{~kg} / \mathrm{t}$-dust \\
\hline Top gas temperature & $650-980{ }^{\circ} \mathrm{C}$ \\
\hline Post combustion ratio* & $0.03-0.2$ \\
\hline *) Pc02/(Pc0+Pc02)
\end{tabular}

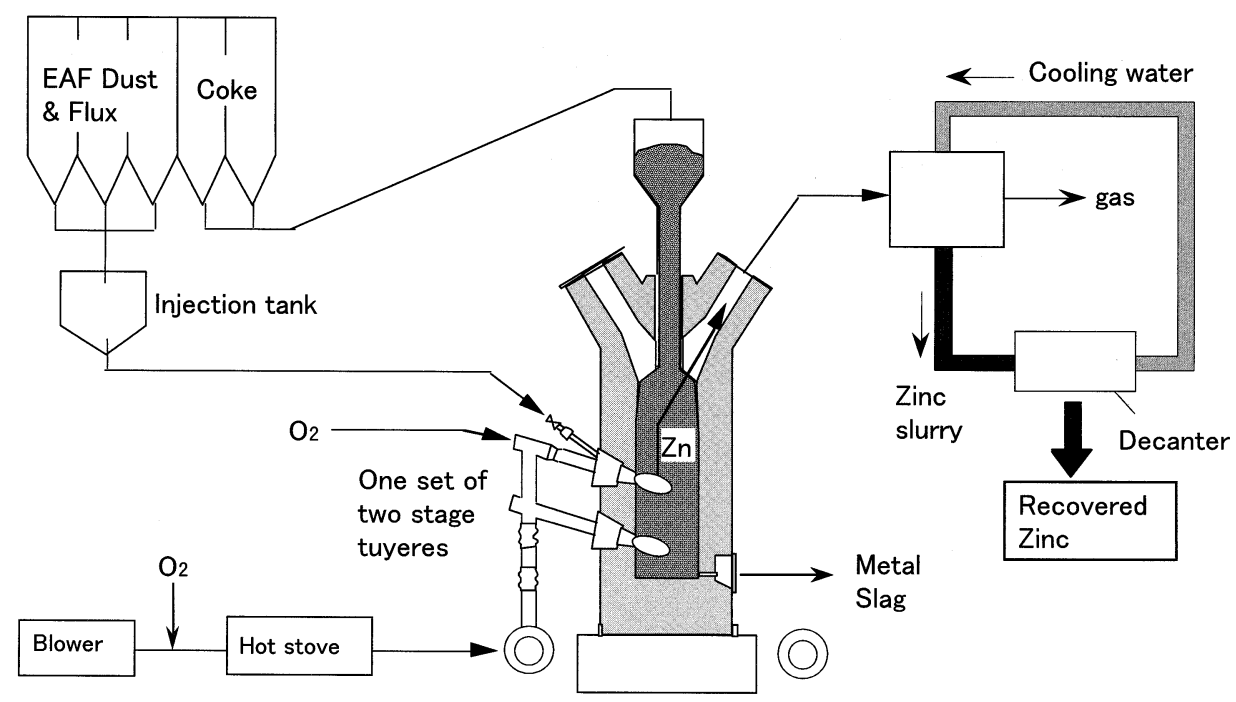

Fig. 3. Process flow of pilot plant for EAF dust recycling. 
Table 9. An example of produced metal and slag composition.

\begin{tabular}{|l|l|l|c|}
\hline \multicolumn{2}{|c|}{ metal } & \multicolumn{2}{c|}{ slag } \\
\hline $\mathrm{C}$ & 4.2 & $\mathrm{CaO}$ & 37 \\
$\mathrm{Si}$ & 2.5 & $\mathrm{SiO}_{2}$ & 36 \\
$\mathrm{Mn}$ & 1.7 & $\mathrm{Al}_{2} \mathrm{O}_{3}$ & 15 \\
$\mathrm{P}$ & 0.28 & $\mathrm{MgO}$ & 6 \\
$\mathrm{~S}$ & 0.09 & $\mathrm{Fe}$ & 1.5 \\
$\mathrm{Zn}$ & 0.005 & $\mathrm{Zn}$ & 0.01 \\
$\mathrm{~Pb}$ & 0.001 & $\mathrm{~Pb}$ & 0.001 \\
$\mathrm{Cu}$ & 0.52 & $\mathrm{Cu}$ & 0.01 \\
$\mathrm{Cr}$ & 0.63 & $\mathrm{Cr}$ & 0.12 \\
\hline
\end{tabular}

Table 10. An example of recovered product composition.

\begin{tabular}{|c|c|c|c|c|c|c||l|}
\hline $\mathrm{T} . \mathrm{Zn}$ & $\mathrm{T} . \mathrm{Fe}$ & $\mathrm{Pb}$ & $\mathrm{C}$ & $\mathrm{SiO}_{2}$ & $\mathrm{Al}_{2} \mathrm{O}_{3}$ & $\mathrm{CaO}$ & Dioxin \\
\hline 60 & 1.71 & 6.2 & 2.27 & 2.93 & 1.14 & 1.75 & $0.0001 \mathrm{ng} / \mathrm{g}$ \\
\hline
\end{tabular}

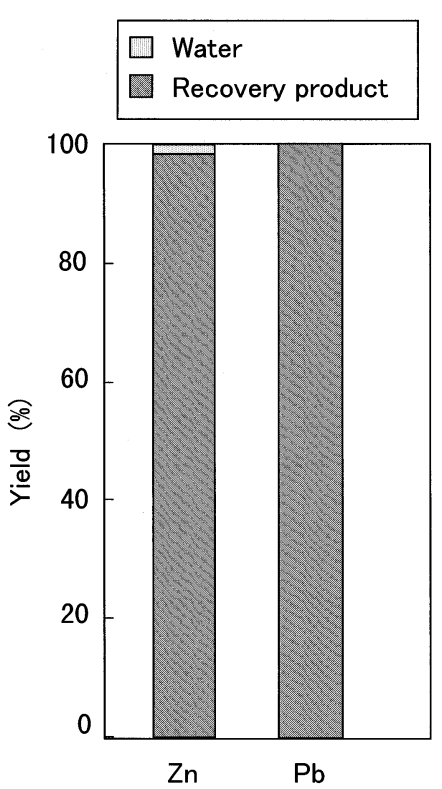

Fig. 4. Material balance of zinc and lead.

material balance of zinc and lead. The yield of the elements with high vapor pressure such as zinc and lead to the recovered product is more than $99 \%$. Soluble zinc in the water is precipitated by neutralization and can be effectively used as zinc resource with the recovery product.

EAF dust contains dioxins as shown in Table 7. But the concentration of dioxins in the recovered product through the furnace top was $0.0001 \mathrm{ng} / \mathrm{g}$ in concentration of toxic equivalent. This indicates that dioxins decomposed in the raceway of the smelting reduction furnace cannot be resynthesized in the region between the furnace top and the quenching equipment because the top gas maintained at high temperature is quenched by water spray.

Figure 5 shows zinc and iron contents of the metal and the slag in the region between upper and lower tuyeres. ${ }^{10)}$ The probe inserted into the furnace sampled the metal and the slag in the region. Figure 5 presents that the iron and zinc oxides fused in the upper raceway are almost reduced to metal during the dripping through the region, and that the reduction rate of zinc oxide are greater than that of iron

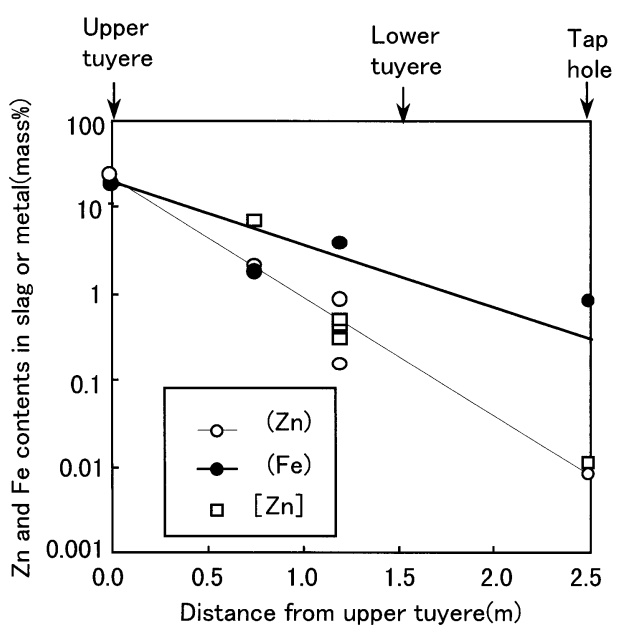

Fig. 5. Zinc and iron contents in metal and slag in the region between upper and lower tuyeres.

oxide.

\section{Discussion}

\subsection{Control of the Thermal State of the Furnace and Smelting Reduction Behavior}

The furnace is relatively small and the hot metal temperature does not indicate directly the thermal state of the furnace because the heat loss depends on the production rate. The reduction condition is affected by the temperature at the level of the lower tuyeres. Thus, the estimated metal temperature at the level of the lower tuyeres, $T_{\text {melt }}$, is introduced as the indicator of the furnace thermal state. $T_{\text {melt }}$ can be calculated by Eq. (1):

$$
T_{\text {melt }}=T_{\text {tap }}+Q_{\text {loss }, \mathrm{h}} /\left(W_{\mathrm{m}} C_{\mathrm{m}}+W_{\mathrm{s}} C_{\mathrm{s}}\right) .
$$

where, $T_{\text {tap }}, Q_{\text {loss,h }}, W$, and $C$ denote the metal temperature at tapping, the heat loss from the furnace hearth, metal or slag production, and the specific heat of molten metal or slag.

The relationships between $T_{\text {melt }}$ and the silicon content of the metal, [Si], the chromium and iron contents of the slag, (T.Cr) and (FeO), and the manganese distribution partition, $(\mathrm{MnO}) /[\mathrm{Mn}]$, in the commercial plant operation for BOF dust recycling are shown in Fig. 6. [Si] is known as an indicator of the thermal state of the operation, and (T.Cr), $(\mathrm{FeO})$, and $(\mathrm{MnO}) /[\mathrm{Mn}]$ indicate the state of reduction. [Si] increases and (T.Cr), $(\mathrm{FeO})$, and $(\mathrm{MnO}) /[\mathrm{Mn}]$ decrease with the increase in the $T_{\text {melt }}$. Figure 6 presents that $T_{\text {melt }}$ is a valid indicator which indicates the thermal state of the furnace and the state of reduction, and that $T_{\text {melt }}$ higher than 1 $550^{\circ} \mathrm{C}$ is the condition required for the smelting reduction of chromium and iron.

Figure 7 shows the relationship between $T_{\text {melt }}$ and (T.Cr) in the pilot plant tests for both BOF dust recycling and the reduction of chromium ore ${ }^{2)}$ which had operated before. (T.Cr) decreases with an increase in the $T_{\text {melt }}$ for both BOF dust and chromium ore. At the same $T_{\text {melt }}$, however, (T.Cr) in the smelting reduction of BOF dust is lower than that in the reduction of chromium ore. This means that the BOF dust is easier to reduce than chromium ore.

In the pilot plant operation for EAF dust recycling, $T_{\text {melt }}$ 

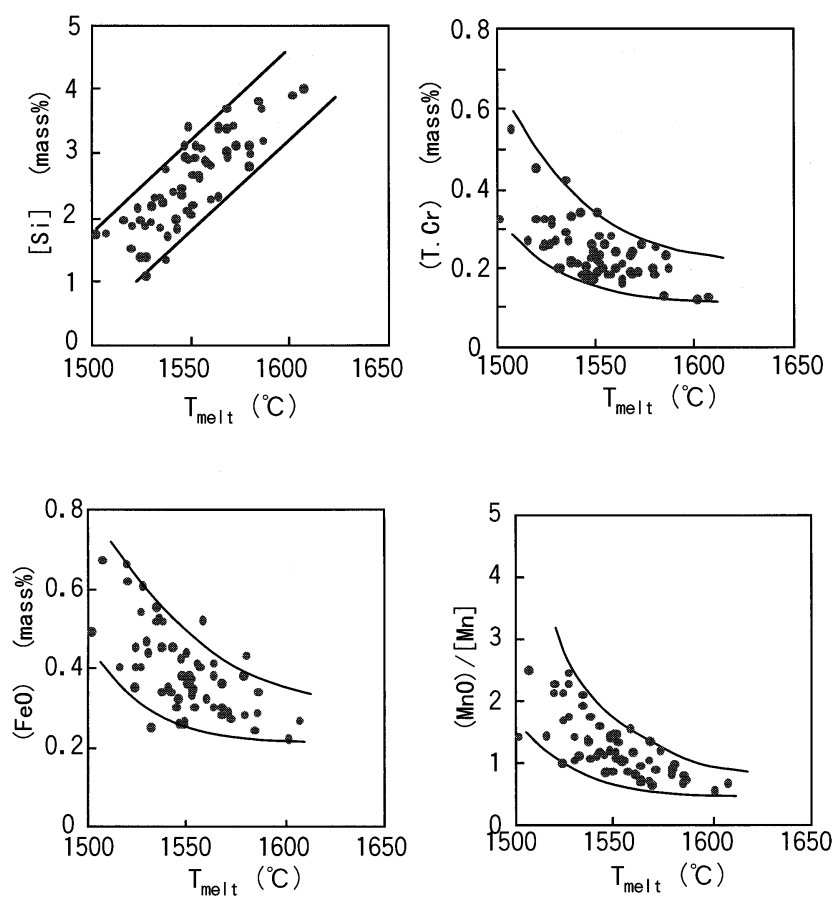

Fig. 6. Relationship between $T_{\text {melt }}$ and [Si], (T.Cr), and $(\mathrm{MnO}) /[\mathrm{Mn}]$ in the commercial plant operation for BOF dust recycling. Metal production is $120-200$ tons per day. Plots are daily data in the commercial plant operation.

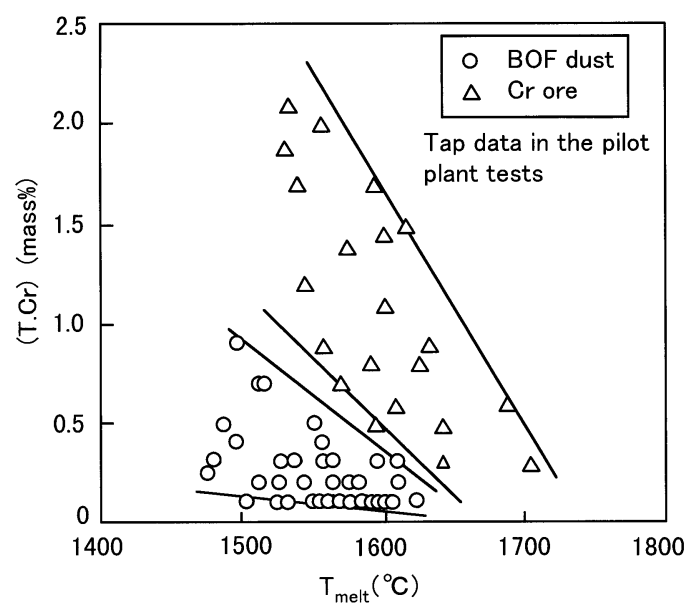

Fig. 7. Relationship between $T_{\text {melt }}$ and (T.Cr) in the pilot plant tests for both BOF dust and $\mathrm{Cr}$.

was almost 1500 to $1600^{\circ} \mathrm{C}$ during the operation, and under the thermal state, zinc and lead contents of the slag were lower than $0.01 \mathrm{mass} \%$ and $0.001 \mathrm{mass} \%$, respectively. This result indicates that zinc oxide is almost reduced even at the thermal state, $1500^{\circ} \mathrm{C}<T_{\text {melt }}<1550^{\circ} \mathrm{C}$, at which chromium and iron oxides can not be completely reduced, and thus the operational condition should be controlled by considering the reduction of chromium and iron oxides in EAF dust recycling.

The index, $\eta$, presented by the next equation is introduced as the factor which controls the $T_{\text {melt: }}$ :

$$
\eta=\text { Qreq } /(\text { Qin }- \text { Qloss }) \text {. }
$$

where, Qreq, Qin, and Qloss are the sum of the direct reduction heat of the oxides in the raw material and the sensible heat of the produced molten metal and slag, the sum of

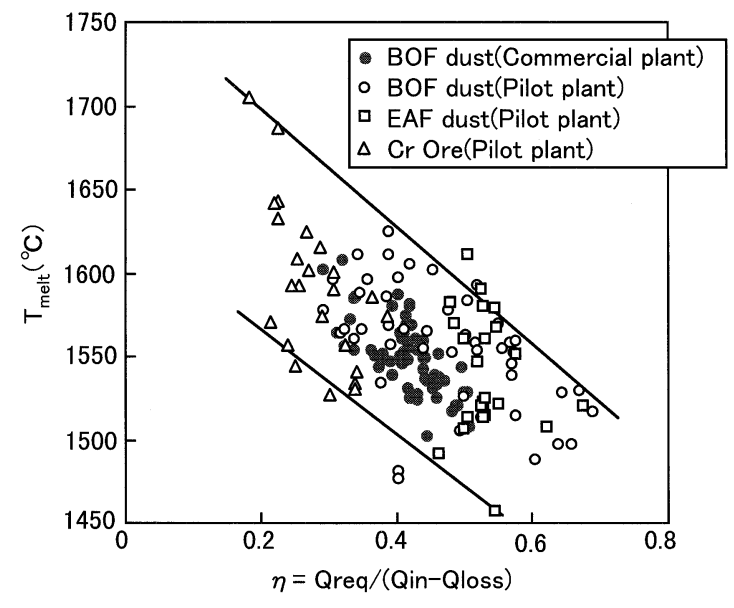

Fig. 8. Relationship between $\eta$ and $T_{\text {melt }}$.

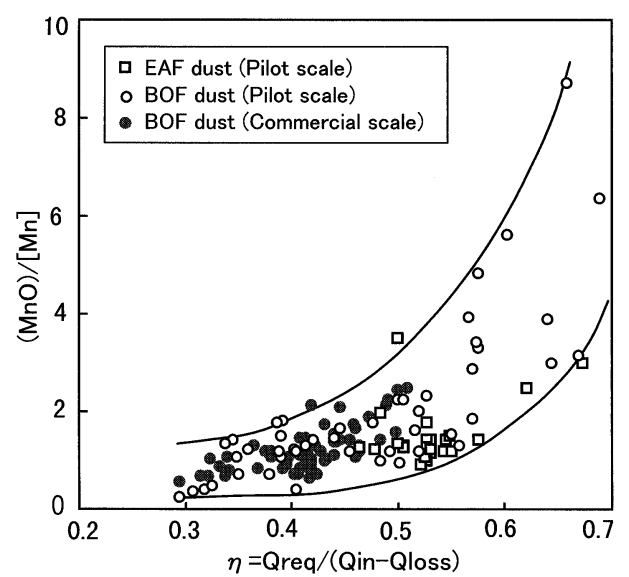

Fig. 9. Relationship between ratio of necessary heat for smelting reduction to effective heat of input and manganese distribution partition.

the combustion heat of coke to $\mathrm{CO}$ and the sensible heat of the hot blast, and the heat loss of the furnace, respectively. $\eta$ is the operational factor which is presented by the ratio of the smelting heat of raw material to the effective input heat. Figures 8 and 9 show the relationships between $\eta$ and $T_{\text {melt }}$ and $(\mathrm{MnO}) /[\mathrm{Mn}]$. These figures show that $T_{\text {melt }}$ is controlled by $\eta$ and the state of reduction is also presented by $\eta$. $(\mathrm{MnO}) /[\mathrm{Mn}]$ increases remarkably when $\eta$ exceeds 0.5 as shown in Fig. 9. Furthermore, (T.Cr), $(\mathrm{FeO})$, and $(\mathrm{MnO}) /$ [Mn] increase remarkably when $T_{\text {melt }}$ is less than $1550^{\circ} \mathrm{C}$ as shown in Fig. 6. Thus in the commercial plant operation, the blast condition is controlled so that $T_{\text {melt }}$ becomes $1550^{\circ} \mathrm{C}$.

Furthermore, Fig. 9 includes the two types of plant scale and raw material, and so the relationship can be used to plan the basic operational condition in various cases of plant scale and raw material. ${ }^{8)}$

\subsection{Temperature in Smelting Reduction Region}

In this process, the smelting reduction is carried out in the region between upper and lower tuyeres. It can be considered that $T_{\text {melt }}$ presents the average temperature in the smelting reduction region because $T_{\text {melt }}$ indicates the state of the reduction and is controlled by the blast condition as shown in the previous section.

On the other hand, the temperature in the smelting reduc- 


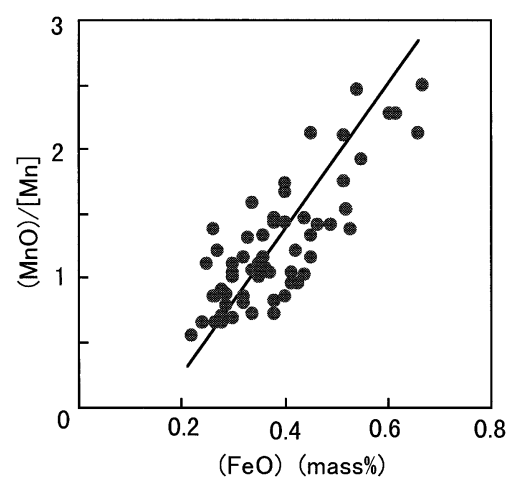

Fig. 10. Relationship between $(\mathrm{FeO})$ and $(\mathrm{MnO}) /[\mathrm{Mn}]$ in the commercial plant operation.

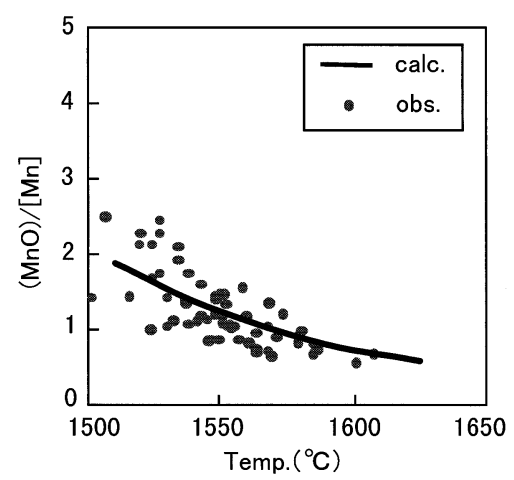

Fig. 11. Relationship between temperature in the smelting reduction region and $(\mathrm{MnO}) /[\mathrm{Mn}]$.

tion region has, as below, been estimated under the assumption that the next reaction is in equilibrium.

$$
\begin{array}{r}
{[\mathrm{Mn}]+(\mathrm{FeO})=(\mathrm{MnO})+\mathrm{Fe} . \ldots \ldots \ldots . . .} \\
\log \left\{a_{\mathrm{MnO}} /\left(a_{\mathrm{Mn}} \cdot a_{\mathrm{FeO}}\right)\right\}=6440 / T-2.95^{11)}
\end{array}
$$

Equation (5) is deduced from Eq. (4):

$$
\begin{aligned}
\log (\mathrm{MnO}) /[\mathrm{Mn}]= & \log a_{\mathrm{FeO}}+6440 / T-2.93 \\
& +\log f_{\mathrm{Mn}}-\log \gamma_{\mathrm{MnO}} \ldots \ldots \ldots
\end{aligned}
$$

where, $\log f_{\mathrm{Mn}}=e_{\mathrm{Mn}}^{\mathrm{C}}[\operatorname{mass} \% \mathrm{C}]+e_{\mathrm{Mn}}^{\mathrm{Si}}[\mathrm{mass} \% \mathrm{Si}]+e_{\mathrm{Mn}}^{\mathrm{Cr}}[\mathrm{mass} \%$ $\mathrm{Cr}], e_{\mathrm{Mn}}^{\mathrm{C}}=-0.07, e_{\mathrm{Mn}}^{\mathrm{Si}}=-0.017, e_{\mathrm{Mn}}^{\mathrm{Cr}}=0.0039^{12)}$, and $\gamma_{\mathrm{MnO}}=$ $10^{-3} \times\left\{5.9 \times((\operatorname{mass} \% \mathrm{CaO})+1.4(\operatorname{mass} \% \mathrm{MgO})) /\left(\operatorname{mass} \% \mathrm{SiO}_{2}\right)\right.$ $+1.6\}{ }^{13)}$ Activity of $\mathrm{FeO}$ is from Arato et al. ${ }^{14)}$

Figure 10 shows the relationship between $(\mathrm{FeO})$ and $(\mathrm{MnO}) /[\mathrm{Mn}]$ in the case of the BOF dust recycling during the commercial plant operation. The temperature which corresponds to each plot in Fig. 10 can be calculated by both the relationship shown in Fig. 10 and Eq. (5). Figure 11 shows the relationship between the calculated temperature and $(\mathrm{MnO}) /[\mathrm{Mn}]$ with the observed values shown in Fig. 6. The calculated result has the same tendency as the observed one. Thus it can be thought that $T_{\text {melt }}$ is the valid indicator which presents the average temperature in the smelting reduction region.

\subsection{Vaporization Behavior}

The vaporization behavior of the elements contained in EAF dust is discussed below by using results of pilot plant tests for EAF dust recycling. Figure 12 shows the relationship between the vapor pressure, $P_{\text {meas. }}$, calculated by Eq.

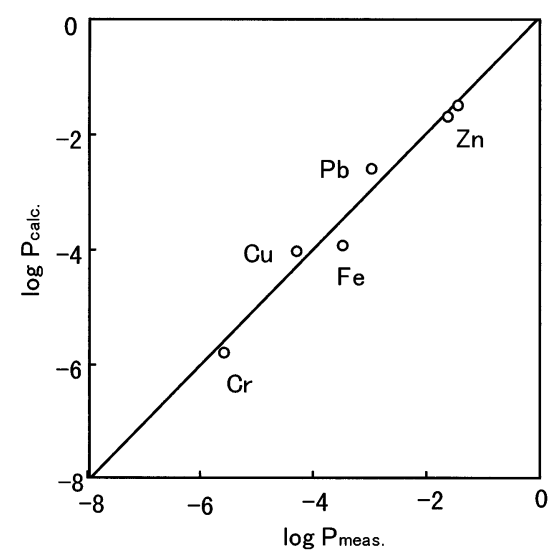

Fig. 12. Relationship between vapor pressure $P_{\text {meas. }}$ and $P_{\text {calc. }}$.

(6) and that, $P_{\text {calc, }}$, calculated by Eq. (7).

$$
\begin{gathered}
P_{\text {meas. }}=P_{\mathrm{g}} \cdot V_{i} / V_{\mathrm{g}} \cdot . \\
P_{\text {calc. }}=\gamma_{i}^{0} \cdot P_{i}^{0} \cdot \chi_{i} \ldots
\end{gathered}
$$

where, $P_{\mathrm{g}}, V_{i}, V_{\mathrm{g}}, \gamma_{i}^{0}, P_{i}^{0}$, and $\chi_{i}$ denote the top gas pressure (atm), the vapor volume of element, $i$, calculated by the amount in the recovered product $\left(\mathrm{Nm}^{3} / \mathrm{h}\right)$, the top gas volume $\left(\mathrm{Nm}^{3} / \mathrm{h}\right)$, Raoultian activity coefficient at infinite dilution, ${ }^{15)}$ vapor pressure in their pure states (atm), and mole fraction of $i$ component in liquid iron, respectively. $P_{\text {meas. }}$ is the vapor pressure calculated from the amount of the element, $i$, in the recovered product and $P_{\text {calc. }}$ is the vapor pressure calculated from the equilibrium between molten metal and the gas phase. $P_{i}^{0}$ in Eq. (7) is calculated by using the $T_{\text {melt }}$ at which the operation was carried out. Values of the $T_{\text {melt }}$ are $1580^{\circ} \mathrm{C}$ and $1660^{\circ} \mathrm{C}$ for zinc, and $1580^{\circ} \mathrm{C}$ for other elements. The vapor pressure, $P_{\text {meas. }}$, almost agrees with the vapor pressure, $P_{\text {calc. }}$, as shown in Fig. 12. Each element supplied in the furnace is reduced and distributed to the liquid iron and the gas phase on the basis of the equilibrium presented by Eq. (7).

These results shown in Tables 9 and 10 and Figs. 4 and 12 indicate that high reducibility is achieved in the process, and prove the basic principle of the process that zinc and iron can be separately recovered. Considering this vaporization behavior with the discussion on the reduction behavior in the previous session, 5-1, the smelting reduction and the vaporization are carried out in the furnace as follows:

- chromium and iron in BOF dust and EAF dust are almost reduced to metal at $T_{\text {melt }}$ higher than $1550^{\circ} \mathrm{C}$ and then are tapped through the tap hole.

- zinc and lead in EAF dust are almost completely reduced to metal and then all the amount of zinc and lead are vaporized at $T_{\text {melt }}$ higher than $1550^{\circ} \mathrm{C}$.

\subsection{Prevention of Zinc Adhesion}

In the case of zinc bearing dust recycling, the prevention of the zinc adhesion on the wall of the furnace top is important to operate continuously. Figure 13 shows the equilibrium of zinc and zinc oxide presented by Eqs. (8) and (9).

$$
\begin{gathered}
\mathrm{Zn}+\mathrm{CO}_{2}=\mathrm{ZnO}+\mathrm{CO} \ldots \ldots \ldots \ldots \ldots \ldots \ldots \\
\Delta G^{\circ}=-179284+113.1 T^{16)} \quad(\mathrm{J} / \mathrm{mol}) . .
\end{gathered}
$$




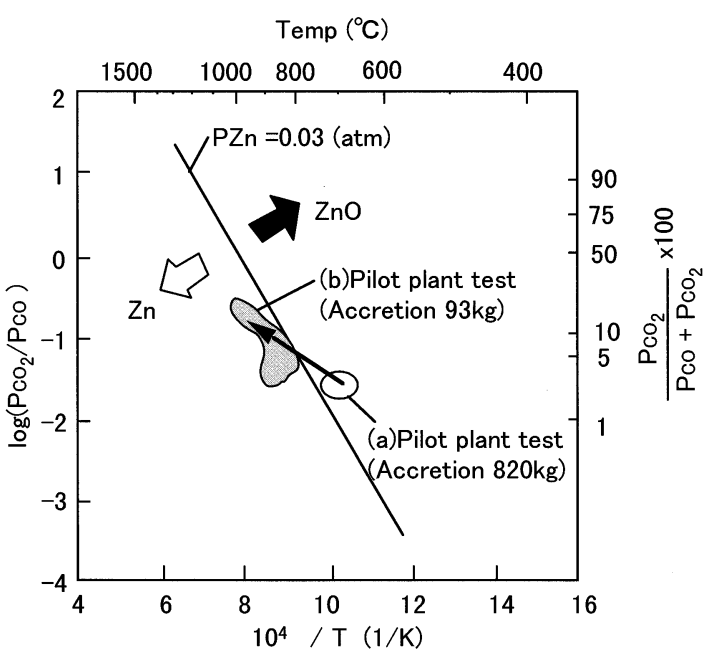

Fig. 13. $\mathrm{Zn} / \mathrm{ZnO}$ equilibrium.

Two regions, (a) and (b), marked in this figure show temperature and $\mathrm{CO}_{2} / \mathrm{CO}$ ratio of the top gas in the second and third campaigns of the pilot plant tests for EAF dust recycling, respectively. Figures indicated in each region show the amount of accretion on the wall of the furnace top and the duct between the furnace and the quenching equipment. In the second campaign, temperature and $\mathrm{CO}_{2} / \mathrm{CO}$ ratio of the top gas was in the region where zinc oxide was stable, and there was a very large amount of accretion on the wall. On the other hand, in the third campaign, because the top gas temperature was raised higher than $900^{\circ} \mathrm{C}$ by the post combustion in the furnace top, temperature and $\mathrm{CO}_{2} / \mathrm{CO}$ ratio of the top gas was in the region where zinc vapor was stable. This condition resulted in a remarkable decrease in the amount of the accretion.

The contents of silica and alumina in the recovered product increased and zinc content decreased with a increase in the coke rate of the smelting reduction operation in benchscale and pilot plant tests. Thus, if the top gas temperature is caused to raise by means of the increase in coke rate in the furnace operation, the zinc content of the recovered product decreases. So, the top gas temperature should be kept higher than $900^{\circ} \mathrm{C}$ by the post combustion in the furnace top.

\section{Conclusion}

The technologies for valuable metal recycling from steelmaking dust by the smelting reduction process with a coke packed bed were described.
(1) The commercial plant for BOF dust recycling has been operating stably with a metal production capacity of 200 tons per day.

(2) The key technologies for EAF dust recycling were established through pilot plant tests with a scale of 10 tons per day.

(3) The temperature of the smelting reduction region can be presented by the indicator of the furnace thermal state, $T_{\text {melt }}$. Chromium in BOF dust is almost reduced at $T_{\text {melt }}$ higher than $1550^{\circ} \mathrm{C}$. Zinc in EAF dust is completely reduced and vaporized at the same thermal state.

(4) $T_{\text {melt }}$ can be controlled by the ratio of the amount of the heat required for the smelting reduction to the input heat.

(5) It is important to prevent the zinc adhesion on the wall of the furnace top that top gas temperature and $\mathrm{CO}_{2} / \mathrm{CO}$ are kept in the region where zinc vapor is stable.

\section{References}

1) T. Hamada, S. Takeuchi, K. Igawa, H. Katayama, H. Itaya and K. Nakanishi: Pyrometallurgy '87 Symposium, The Institute of Mining Metallurgy, London, (1987), 435.

2) H. Itaya, S. Taguchi, K. Igawa and T. Nozaki: Proc. 1st Int. Chromium Steel and Alloys Cong., SAIMM, Johannesburg, (1992), 253.

3) M. Matsuno, Y. Ojima and A. Kaikake: An Int. Symp. on Extraction and Applications of Zinc and Lead, The Mining \& Materials Processing Institute of Japan, Tokyo, (1995), 432.

4) Y. Hara, N. Ishiwata, S. Miyagawa, H. Itaya, M. Nomura and T. Matsumoto: CAMP-ISIJ, 10 (1997), 18.

5) Y. Nabeshima, K. Taoka, S. Yamada, S. Hamada, Y. Sakurai and Y. Masuda: CAMP-ISIJ, 8 (1995), 1139.

6) N. Ishiwata, T. Sato, S. Miyagawa, Y. Hara and H. Itaya: CAMP-ISIJ, 10 (1997), 980.

7) T. Sato, N. Ishiwata, S. Miyagawa, Y. Hara and H. Itaya: CAMP-ISIJ, 10 (1997), 981

8) N. Ishiwata, T. Sato, Y. Hara, and H. Itaya: CAMP-ISIJ, 11 (1998), 783.

9) Kagaku Kohgaku Binran Kaitei 5th Ed., Maruzen, Tokyo, (1988), 684.

10) N. Ishiwata, Y. Hara, and H. Itaya: CAMP-ISIJ, 12 (1999), 119.

11) M. Ohtani: Tetsu Yakin Netsurikigaku, Nikkan Kohgyo Shinbunsha, Tokyo, (1971), 212.

12) Handbook of Iron and Steel, 3rd Ed., ed. by ISIJ, vol. 1, Maruzen, Tokyo, (1981), 20.

13) N. Tsuchiya, S. Taguchi, Y. Takada and K. Okabe: Tetsu-to-Hagané, 63 (1977), 1791.

14) T. Arato, M. Tokuda and M. Ohtani: Tetsu-to-Hagané, 68 (1982), 2263.

15) M. Hino, S. Wang, T. Nagasaka and S. Ban-ya: Tetsu-to-Hagané, 80 (1994), 46.

16) E. T. Turkdogan: Physical Chemistry of High Temperature Technology, Academic Press, London, (1980), 5. 